\title{
Sexual behavior and sexually transmitted infection in the elderly population of South Korea
}

\author{
Hee Youn Kim, Hyun-Sop Choe, Dong Sup Lee, Je Mo Yoo, Seung-Ju Lee \\ Department of Urology, St. Vincent's Hospital, College of Medicine, The Catholic University of Korea, Seoul, Korea
}

Purpose: To study the sexual behavior and status of sexually transmitted urethritis (STU) in the elderly population of South Korea. Materials and Methods: Congregating places for elderly population, which were selected on the expected risk of sexually transmitted infections, were visited to study their sexual behavior, awareness on sexually transmitted diseases (STDs), and STU status using a specially developed survey and urine polymerase chain reaction (PCR) test. In addition, analysis of the Health Insurance Review \& Assessment Service (HIRA) database was done to study the nationwide status and trends of STU of the elderly population.

Results: The study found that approximately $42 \%$ of elderly South Koreans were sexually active. Elderlies in the high-risk group showed a higher percentage of multiple sexual partners and prostitution than elderlies in the low-risk group. Only $3 \%$ and $14 \%$ in the low-risk group and high-risk group used condoms, showing a very low rate of condom use. Both the urine PCR results and HIRA database analysis showed that the prevalence of STU was not high and it remained stable in recent years, implying that currently, STU is not a significant burden on public health in the elderly population of South Korea.

Conclusions: The current study presented the sexual behavior in the elderly population of South Korea, as well as the recent prevalence and trend of STU in the elderly population. These results may be used as baseline data for future study, education, prevention and public campaign plan for STDs in the elderly population.

Keywords: Aged; Sexual behavior; Sexually transmitted diseases

This is an Open Access article distributed under the terms of the Creative Commons Attribution Non-Commercial License (http://creativecommons.org/licenses/by-nc/4.0) which permits unrestricted non-commercial use, distribution, and reproduction in any medium, provided the original work is properly cited.

\section{INTRODUCTION}

The World Health Organization and the United Nations classified population aging into three categories according to the percentage of population aged over 65 years: aging society when the proportion is over $7 \%$, aged society when the proportion is over $14 \%$, and super-aged society when the proportion is over 20\% [1]. South Korea is one of the fastest aging countries in the world. It has become an aging society in 2000 , aged society in 2017 , and is expected to become a super-aged society in 2026 [2,3]. Medical science has undoubtedly contributed to this population aging, and as a result, the number and proportion of elderly people who maintain sexual activity is thought to be higher than in the past and is expected to rise continually in the future.

However, despite this rapid change, social recognition of sexual needs and realities of its elderly population tends to be slow [4]. It is even a taboo subject in many Asian countries including South Korea. As a result, sexual activity in the elderly tends to take place in the shade. In the

Received: 13 December, 2018 - Accepted: 17 February, 2019

Corresponding Author: Seung-Ju Lee

Department of Urology, St. Vincent's Hospital, College of Medicine, The Catholic University of Korea, 93 Jungbu-daero, Paldal-gu, Suwon 16247, Korea TEL: +82-31-249-7473, FAX: +82-31-253-0949, E-mail: seungju@catholic.ac.kr

ORCID: https://orcid.org/0000-0003-0072-8010 
absence of a spouse, which is common in the elderly, many may resort to prostitution to fulfill their sexual needs and recently this has been a social issue in the form of "Bacchus ladies" in South Korea [5,6]. "Bacchus ladies" is a term for poor elderly women selling sex to elderly men for a living, generally at urban public parks where elderlies congregate. This naturally raises concerns for sexually transmitted diseases (STDs) in the elderly population.

STDs in the elderly population is a subject that has been neglected from public campaign for prevention and education of STDs, STDs-related researches, and even healthcare professionals because the incidence is considerably low compared to that of the younger population [7-10]. As population aging progresses and proportion of elderlies maintaining sexual activity grows, STDs can be a potential healthcare problem for the elderly population, especially for those exposed to unprotected sex and prostitution as in the cases of "Bacchus ladies." Also, elderlies are more susceptible to STDs because of low use of condoms and decreased immunity $[4,9,11]$.

In light of these findings, there is a growing need for an accurate assessment of the current status of STDs in the elderly population. Sexual behavior of the elderly population should also be assessed in conjunction with the status of STDs, because knowledge of social dynamics, rituals, and sexual practices of the elderly are necessary to delineate obstacles to change and to determine the most effective way to reach this group [12]. The current study attempted to assess these problems to provide basic data for establishing STDs prevention, education and public campaign plan for the elderly population.

\section{MATERIALS AND METHODS}

This study was conducted on two fronts. First, congregating places for elderly population were selected and visited by our researchers to study their sexual behavior, awareness on STDs, and sexually transmitted urethritis (STU) status. Second, Analysis of the Health Insurance Review \& Assessment Service (HIRA) database was done to study the nationwide status and trends of STU of the elderly population. The Institutional Review Board of The Catholic University of Korea, St. Vincent's Hospital approved the study protocol (approval number: VC15QCSI0131).

\section{Visits to congregating places for the elderly population}

We hypothesized that sexual behavior and risk of STDs infection in the elderly population would be different depending on congregating places. As such, congregating places for the elderlies were selected on the basis of risk of STDs infection. Senior welfare centers were selected as places where risk of STDs infection is expected to be low, and urban public parks were selected as places where risk of STDs infection is expected be high. To find out the nationwide status, multiple places were selected around the country. For the study of the elderlies with low risk of STDs, senior welfare center in the city of Incheon and Ulsan were selected, and for the study of the elderlies with high risk of STDs, Jongmyo Park in the city of Seoul and Dalseong Park in the city of Daegu were selected. Visits were made between July 2015 and December 2015. Informed consent was received from all elderlies who volunteered for the study. They were first asked to fill out a survey on sexual behavior and STDs awareness, developed for the purpose of the current study (Supplementary material). Then, first-void urine sample was obtained for urine polymerase chain reaction (PCR) test (Seegene Medical Foundation, Seoul, Korea) to test for Neisseria gonorrhoeae, Chlamydia trachomatis, Mycoplasma genitalium and Trichomonas vaginalis. The survey contained components on socioeconomic status, sexual behavior, awareness regarding STDs, STDs status and sexual health education. The results of the survey and urine PCR test of the two groups were compared.

\section{Analysis of the Health Insurance Review \& Assessment Service database}

HIRA database contains all health insurance claims issued by health institutions in South Korea. Since all Koreans are required to enroll in the National Health Insurance Service by law, the HIRA database is a representative data of the whole country. Data on insurance claims with the disease codes containing $N$.gonorrhoeae and C. trachomatis between 2010 and 2016, was analyzed. The actual number and proportion of patients over 65 years of age were investigated and the annual trend was analyzed.

\section{RESULTS}

\section{Survey}

Table 1 describes the baseline demographics and socioeconomic status of the elderlies who completed the survey. There were a total of 337 participants aged over 60, 204 in the low-risk group and 133 in the high-risk group. The distribution of age group was similar between the two groups. The distribution of sex was different; male to female ratio was 47.5:52.5 in the low-risk group, whereas in the high- 
Table 1. Baseline information

\begin{tabular}{|c|c|c|c|}
\hline & Total & Low-risk group & High-risk group \\
\hline Total & $337(100.0)$ & $204(60.5)$ & $133(39.5)$ \\
\hline \multicolumn{4}{|l|}{ Age (y) } \\
\hline $60-64$ & $16(4.7)$ & $15(7.4)$ & $1(0.8)$ \\
\hline $65-70$ & $77(22.8)$ & $56(27.5)$ & $21(15.8)$ \\
\hline $71-80$ & $185(54.9)$ & $105(51.5)$ & $80(60.2)$ \\
\hline $81-90$ & $52(15.4)$ & $24(11.8)$ & $28(21.1)$ \\
\hline$\geq 91$ & $7(2.1)$ & $4(2.0)$ & $3(2.3)$ \\
\hline \multicolumn{4}{|l|}{ Sex } \\
\hline Male & $214(63.5)$ & $97(47.5)$ & $117(88.0)$ \\
\hline Female & $123(36.5)$ & $107(52.5)$ & $16(12.0)$ \\
\hline \multicolumn{4}{|l|}{ Education } \\
\hline None & $31(9.2)$ & $15(7.4)$ & $16(12.0)$ \\
\hline Elementary school & $111(32.9)$ & $52(25.5)$ & $59(44.4)$ \\
\hline Middle school & $76(22.6)$ & $54(26.5)$ & $22(16.5)$ \\
\hline High school & $92(27.3)$ & $68(33.3)$ & $24(18.0)$ \\
\hline College & $25(7.4)$ & $13(6.4)$ & $12(9.0)$ \\
\hline \multicolumn{4}{|l|}{ Marital status } \\
\hline Married & $242(71.8)$ & $148(72.5)$ & $94(70.7)$ \\
\hline Bereaved & $82(24.3)$ & $49(24.0)$ & $33(24.8)$ \\
\hline Divorced & $11(3.3)$ & $7(3.4)$ & $4(3.0)$ \\
\hline Not married & $1(0.3)$ & $0(0.0)$ & $1(0.8)$ \\
\hline Etc. & $1(0.3)$ & $0(0.0)$ & $1(0.8)$ \\
\hline \multicolumn{4}{|l|}{ Employment } \\
\hline Employed & $30(8.9)$ & $23(11.3)$ & $7(5.3)$ \\
\hline Not employed & $304(90.2)$ & $179(87.7)$ & $125(94.0)$ \\
\hline \multicolumn{4}{|l|}{ Past occupation } \\
\hline None or housewife & $36(10.7)$ & $35(17.2)$ & $1(0.8)$ \\
\hline Private company & $78(23.1)$ & $54(26.5)$ & $24(18.0)$ \\
\hline Government & $18(5.3)$ & $14(6.9)$ & $4(3.0)$ \\
\hline Professional & $17(5.0)$ & $14(6.9)$ & $3(2.3)$ \\
\hline Education & $10(3.0)$ & $6(2.9)$ & $4(3.0)$ \\
\hline Self-employed & $82(24.3)$ & $38(18.6)$ & $44(33.1)$ \\
\hline Agriculture/forestry/fishing & $30(8.9)$ & $14(6.9)$ & $16(12.0)$ \\
\hline Etc. & $64(19.0)$ & $27(13.2)$ & $37(27.8)$ \\
\hline \multicolumn{4}{|l|}{ Income level } \\
\hline Low & $131(38.9)$ & $61(29.9)$ & $70(52.6)$ \\
\hline Middle-low & $42(12.5)$ & $34(16.7)$ & $8(6.0)$ \\
\hline Middle & $130(38.6)$ & $84(41.2)$ & $46(34.6)$ \\
\hline Middle-high & $22(6.5)$ & $18(8.8)$ & $4(3.0)$ \\
\hline High & $11(3.3)$ & $6(2.9)$ & $5(3.8)$ \\
\hline
\end{tabular}

Values are presented as number (\%).

risk group, it was 88.0:12.0, showing male predominance in the high-risk group. The education level and income level was generally higher in the low-risk group.

The rest of the survey components are described in the supplementary tables. Supplementary Tables 1 to 7 describe questions regarding sexual behavior, Supplementary Tables 8 to 11 describe questions regarding STDs awareness and
Supplementary Tables 12 to 14 describe questions regarding sexual health education.

Supplementary Table 1 describes the frequency of sexual intercourse. The overall frequency of sexual intercourse did not show significant difference between the two groups. Respondents who had sexual intercourse over 1 to 2 times per 3 months was $36 \%$ and $32 \%$ in the low-risk and high-risk 
group, respectively. However when stratified by sex, $54 \%$ of males maintained sexual life whereas the number was $31 \%$ for females, implying that males play a more dominant role in sexual life in the elderly population. Supplementary Table 2 describes the number of sexual partners. In the low-risk group, $97.5 \%$ of the respondents had 1 or no sexual partners and only $0.5 \%$ had 3 or more partners. In the high-risk group, $94 \%$ of the respondents had 1 or no sexual partners and $5 \%$ had 3 or more partners. The percentage of respondents who had multiple partners was 3 times higher in the high-risk group. Also, respondents who had multiple partners were all males. Supplementary Table 3 describes the types of sexual partners. In the low-risk group, over $90 \%$ were spouse and only $1 \%$ was prostitutes. In the high-risk group, $70 \%$ were spouse and $7 \%$ was prostitutes, showing a significantly higher percentage of prostitution. Supplementary Table 4 describes condom use during sexual intercourse. The percentage of condom use was $3 \%$ and $14 \%$ in the lowrisk and high-risk group, respectively. Only $1 \%$ in the lowrisk group and $10 \%$ in the high-risk-risk group responded that they used condoms almost always. This result shows that condom use is very low among sexually active elderly population. Supplementary Table 5 describes presence of erectile dysfunction among male respondents. The percentage of moderate to severe erectile dysfunction was $77 \%$ and $80 \%$ in the low-risk and high-risk group, respectively. This result shows that majority of males in both groups suffered from some degree of erectile dysfunction. Supplementary Table 6 describes use of phosphodiesterase -5 inhibitors. The percentage of respondents that used phosphodiesterase- 5 inhibitors was $24 \%$ and $28 \%$ in the low-risk and high-risk group, respectively, showing a similar percentage of use for both groups. Supplementary Table 7 describes contribution of phosphodiesterase-5 inhibitors to sexual life. The percentage of respondents who thought phosphodiesterase- 5 inhibitors helped their sexual life was $31 \%$ and $30 \%$ in the low-risk and high-risk group respectively, showing similar results.

Supplementary Table 8 describes history of STDs infection and time of the infection. The percentage of respondents with history of previous STDs infection was $17 \%$ and $27 \%$ in the low-risk and high-risk group, respectively. In the lowrisk group, none of the past STDs infection occurred within 10 years, whereas in the high-risk group, $9 \%$ of the STDs infection occurred within 10 years. Supplementary Table 9 describes type of STDs. In the low-risk group, urethritis was $6 \%$, gonorrhea $66 \%$, syphilis $6 \%$ and genital herpes $6 \%$. In the high-risk group, urethritis was $17 \%$, gonorrhea $75 \%$ and genital herpes $3 \%$. Gonorrhea was the predominant STD for both groups. Supplementary Table 10 describes type of sexual partner from whom STDs was infected. In both groups, prostitute was the most common sexual partner from whom STDs was infected. It constituted $53 \%$ in the low-risk group and $55 \%$ in the high-risk group, without showing significant difference. Supplementary Table 11 describes places where STDs were treated. In both groups, hospitals were the most common place respondents received treatment for STDs. 86\% of the respondents for both groups received treatment in hospitals.

Supplementary Table 12 describes experience with and intention to receive sexual health education. Approximately $47 \%$ in the low-risk group and $41 \%$ in the high-risk group answered they were willing to receive sexual health education, showing similar response. However, past experience with sexual health education showed significant difference. Approximately 29\% in the low-risk group answered they had experience with sexual health education, whereas only $10 \%$ in the high-risk group experienced sexual health education. This implies that elderlies congregating in senior welfare centers had more opportunities than elderlies congregating in public parks in receiving sexual health education. Supplementary Table 13 describes preferred institution to receive sexual health education for low-risk group and high-risk group, respectively. In the low-risk group 39\% answered they preferred senior welfare centers, and $18 \%$ answered public health centers. In the high-risk group, $51 \%$ answered they preferred public health centers, $16 \%$ answered senior welfare centers and $4 \%$ answered counseling centers. This difference is thought to be due to convenience in approachability depending on their congregating places. Supplementary Table 14 describes preferred person to receive sexual health education. In the low-risk group, 34\% answered they preferred doctor/nurse and $34 \%$ preferred counselor. In the high-risk group, $56 \%$ answered they preferred doctor/nurse and $27 \%$ preferred counselor.

Table 2 describes the urine PCR results of the elderlies who completed the survey. There was one case of $C$. trachomatis in the low-risk group and one case of $M$.

Table 2. Urine polymerase chain reaction results

\begin{tabular}{lcc}
\hline & $\begin{array}{c}\text { Low-risk group } \\
(\mathbf{n}=\mathbf{2 0 8})\end{array}$ & $\begin{array}{c}\text { High-risk group } \\
(\mathbf{n}=139)\end{array}$ \\
\hline Neisseria gonorrhoeae & $0(0.0)$ & $0(0.0)$ \\
Chlamydia trachomatis & $1(0.5)$ & $0(0.0)$ \\
Mycoplasma genitalium & $0(0.0)$ & $1(0.7)$ \\
Trichomonas vaginalis & $0(0.0)$ & $0(0.0)$ \\
\hline
\end{tabular}

Values are presented as number (\%). 
genitalium in the high-risk group.

\section{Analysis of the Health Insurance Review \& Assessment Service database}

Table 3 describes the actual number and percentage of $N$. gonorrhoeae and of $C$. trachomatis infection in population over 65 years of age between 2010 and 2016 from the HIRA database. The overall percentage of $N$. gonorrhoeae infection in population over 65 years of age did not change much between 2010 and 2016. It was $1.8 \%$ in 2010 and 1.9\% in 2016 . When stratified by sex, the percentage of male ranged between $1.3 \%$ to $1.7 \%$ and the percentage of female ranged between $3.0 \%$ to $4.8 \%$. The percentage of $C$. trachomatis infection in population over 65 years of age steadily declined. It was $1.6 \%$ in 2010 and $0.9 \%$ in 2016 . When stratified by sex, the percentage of male declined from $2.7 \%$ in 2010 to $1.3 \%$ in 2016, whereas the percentage of female was stable around $0.8 \%$. Fig. 1 graphically describes this trend.

\section{DISCUSSION}

STDs in the elderly population is a subject that is

Table 3. Number and percentage of Neisseria gonorrhoeae and Chlamydia trachomatis infection in population over 65 years of age between 2010 and 2016 from the Health Insurance Review \& Assessment Service database

\begin{tabular}{|c|c|c|c|c|c|c|}
\hline \multirow{2}{*}{ Year } & \multicolumn{3}{|c|}{ Total number of cases } & \multicolumn{3}{|c|}{ Cases of over 65 years } \\
\hline & Total & Male & Female & Total & Male & Female \\
\hline \multicolumn{7}{|c|}{ Neisseria gonorrhoeae } \\
\hline 2010 & 19,704 & 15,343 & 4,361 & 349 (1.8) & $203(1.3)$ & $146(3.3)$ \\
\hline 2011 & 18,924 & 14,799 & 4,125 & $339(1.8)$ & $206(1.4)$ & $133(3.2)$ \\
\hline 2012 & 16,962 & 12,868 & 4,094 & $313(1.8)$ & $161(1.3)$ & $152(3.7)$ \\
\hline 2013 & 14,191 & 11,386 & 2,805 & $270(1.9)$ & $136(1.2)$ & $134(4.8)$ \\
\hline 2014 & 14,139 & 11,086 & 3,053 & $240(1.7)$ & $131(1.2)$ & 109 (3.6) \\
\hline 2015 & 15,566 & 11,355 & 4,211 & $315(2.0)$ & $189(1.7)$ & $126(3.0)$ \\
\hline 2016 & 15,218 & 11,110 & 4,108 & 294 (1.9) & $169(1.5)$ & $125(3.0)$ \\
\hline \multicolumn{7}{|c|}{ Chlamydia trachomatis } \\
\hline 2010 & 29,803 & 11,511 & 18,292 & $462(1.6)$ & $313(2.7)$ & $149(0.8)$ \\
\hline 2011 & 29,083 & 9,793 & 19,290 & $366(1.3)$ & $184(1.9)$ & $182(0.9)$ \\
\hline 2012 & 29,042 & 8,581 & 20,461 & $348(1.2)$ & $160(1.9)$ & $188(0.9)$ \\
\hline 2013 & 28,984 & 7,276 & 21,708 & $297(1.0)$ & $101(1.4)$ & $196(0.9)$ \\
\hline 2014 & 32,123 & 7,962 & 24,161 & $313(1.0)$ & $117(1.5)$ & $196(0.8)$ \\
\hline 2015 & 38,724 & 10,949 & 27,775 & $327(0.8)$ & $147(1.3)$ & $180(0.6)$ \\
\hline 2016 & 46,121 & 13,376 & 32,745 & $419(0.9)$ & $171(1.3)$ & $248(0.8)$ \\
\hline
\end{tabular}

Values are presented as number only or number (\%).

A

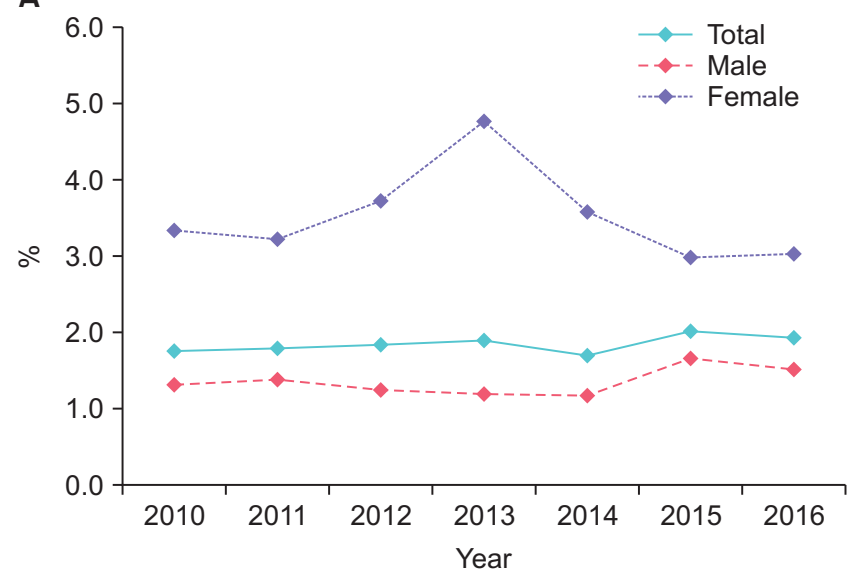

B

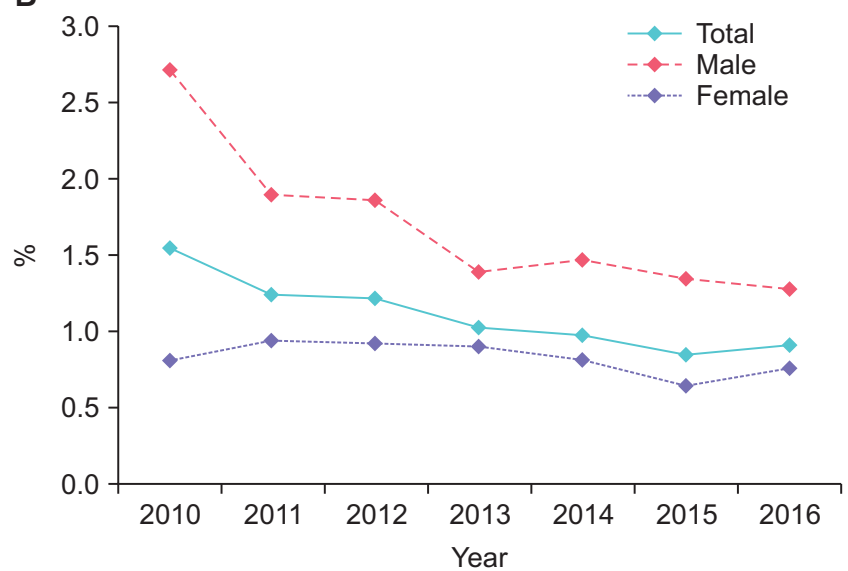

Fig. 1. Trend of (A) Neisseria gonorrhoeae and (B) Chlamydia trachomatis infection in population over 65 years of age between 2010 and 2016 from the Health Insurance Review \& Assessment Service database. 
far from social, academic and clinical interest. There is a general assumption that old people do not have sex and therefore are irrelevant from STDs. This may seem true, as the reported incidence of STDs in the elderly population is considerably lower than that of the sexually active younger population.

However, STDs in the elderly population may pose as a public health issue in the near future, if not for now, for several reasons. First, the elderly are more sexually active than common belief. A study reported that $40 \%$ to $60 \%$ of older adults between ages 60 and 71 was sexually active [13]. Another study also found that $47 \%$ of individuals aged 55 to 75 were sexually active [14]. Sexual activity extends into advanced stage of life, irrespective of sex [9,15]. With rapid aging of the society, the number and proportion of elderlies maintaining sexual activity is expected to increase. Second, with increased sexual activity in the elderly population, the risk of STDs infection may increase. Numerous studies have found the growing incidence of STDs among the elderly population $[9,10,16]$. Third, the actual incidence of STDs in the elderly population may be higher than reported figures because of underreporting, missed diagnosis and noninclusion of asymptomatic carrier [11,12]. Fourth, the rate of condom use is generally very low among elderly population, usually because elderlies are past their reproductive age [7]. Lastly, elderlies are more susceptible to STDs because of physiologic changes related to aging, such as thinning of the vaginal mucosa, friability of cervical tissue due to estrogen deficiencies, and decline in immune function [4,9]. For these reasons, this study was conducted to assess the current status of STDs and sexual behavior in the elderly population and to provide basic data for establishing STDs prevention, education and public campaign plan for the elderly population.

The current study was able to find out several important findings with regard to the sexual behavior of the elderly population in South Korea. The overall frequency of sexual intercourse was $43 \%$ and $41 \%$ in the low-risk group and high risk group respectively, showing similar results with other studies [13-15]. The elderlies in the high-risk group showed a higher percentage of multiple sexual partners and prostitution than the elderlies in the low-risk group. Only $3 \%$ and $14 \%$ in the low-risk group and high-risk group used condoms, showing a very low rate of condom use. With regard to sexual health education, senior welfare centers and public health centers were the preferred institution, and doctor/nurse and counselor was the preferred person for sexual health education.

The current study also looked at the recent prevalence and trend of STU in the elderly population of South Korea. Both the urine PCR results and HIRA database analysis showed that the prevalence was not high and it remained stable in recent years, implying that at least currently, STU is not a significant burden on public health in the elderly population of South Korea, unlike results from other countries. The Centers for Disease Control and Prevention reported that between 2012 and 2016, there was a 56\%, 148\% and $127 \%$ increase of reported cases of chlamydia, gonorrhea and syphilis respectively in the 65 year or older population in the United States [17]. The result of the current study however, does not mean that we can entirely ignore the issue of STDs in the elderly population of South Korea. As described earlier, there is always the issue of underreporting and missed diagnosis, especially when sexual activity and STDs in the elderly population is a taboo subject. Also, several sexual health behaviors found in the current study such as very low rate of condom use and high rate of multiple partners and prostitution especially in the high-risk group, may increase the incidence of STDs in the elderly population of South Korea in the near future, if not for now. Together with rapid population aging, these factors call for a continued monitoring of STDs in the elderly population.

There were several limitations in the current study. First, the number of respondents of the survey was lower than our expectation. Many elderlies showed objection and indifference to the detailed questions on sexual activity, resulting in many unanswered surveys. Second, the PCR and HIRA database study only included STU for practical reasons. Because the study was conducted at open congregating places of elderly population, STDs that require blood sampling such as acquired immune deficiency syndrome and syphilis, were excluded. The same limitation also made us exclude condyloma and genital herpes because these diseases required detailed physical examination in a closed room. Third, although the HIRA database is a representative data of the whole country, it lacks information on uninsured medical claims and it also lacks clinical information such as laboratory tests, height, body weight, past history, etc. Also, there is the issue of inaccurate entry of diagnosis, which is not possible to acknowledge during analysis.

In summary, the current study was able to recognize the current prevalence and trend of STU as well as the sexual behaviors in the elderly population of South Korea. These results may be used as baseline data for future study, education, prevention and public campaign plan for STDs in the elderly population. It can help policy-makers to develop an effective management or surveillance system for 
prevention of STDs in the elderly population, and it can also be used to help produce sexual health education specialists.

\section{CONCLUSIONS}

The current study presented the sexual behavior in the elderly population of South Korea, as well as the recent prevalence and trend of STU in the elderly population. Both the urine PCR study and analysis of the HIRA database showed that the prevalence of STU in the elderly population was low, implying that currently, STU is not a significant public health issue in South Korea. However, several sexual health behaviors found in the current study such as very low rate of condom use, multiple sexual partners and prostitution, together with rapid population aging, call for a continued monitoring of STDs in the elderly population. These results may be used as baseline data for future study, education, prevention and public campaign plan for STDs in the elderly population.

\section{CONFLICTS OF INTEREST}

The authors have nothing to disclose.

\section{ACKNOWLEDGMENTS}

This study was supported by the Foundation for the Korean Urological Association in 2015 (FKUA-2015-001). We would like to thank Inae Park for her contribution to this study.

\section{SUPPLEMENTARY MATERIALS}

Scan this QR code to see the supplementary materials, or visit https://www.icurology.org/src/sm/icurology-60-202-s001.pdf.

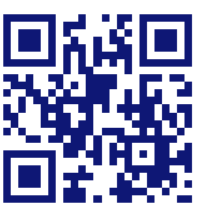

\section{REFERENCES}

1. United Nations Department of Economic and Social Affairs, Population Division. World Population (ST/ESA/SER.A/408) ageing 2017 [Internet]. New York: United Nations Department of Economic and Social Affairs, Population Division; 2017 [cited 2018 Sep 12]. Available from: https://population.un.org/
ProfilesOfAgeing2017/index.html.

2. The Organisation for Economic Co-operation and Development. OECD statistics [Internet]. Paris: The Organisation for Economic Co-operation and Development [cited 2018 Sep 12]. Available from: http://stats.oecd.org/.

3. Statistics Korea. 2017 Statistics on the aged [Internet]. Daejeon: Statistics Korea; 2017 Sep 26 [cited 2018 Sep 12]. Available from: http://kostat.go.kr/portal/eng/pressReleases/11/3/index. board?bmode $=$ read \&bSeq $=\& a S e q=363974 \&$ pageNo $=1 \&$ rowN $\mathrm{um}=10 \&$ navCount $=10 \&$ currPg $=\&$ Target $=$ title $\&$ sTxt $=$.

4. Letvak S, Schoder D. Sexually transmitted diseases in the elderly: what you need to know. Geriatr Nurs 1996;17:156-60.

5. Ng D. Granny prostitutes reflect South Korea's problem of elderly poverty [Internet]. Singapore: Channel NewsAsia; 2017 Jan 29 [cited 2018 Oct 19]. Available from: https://www.channelnewsasia.com/news/asia/granny-prostitutes-reflect-southkorea-sproblem-of-elderly-pove-7562324.

6. Williamson L. The Korean grandmothers who sell sex [Internet]. Seoul: BBC News; 2014 Jun 10 [cited 2018 Oct 19]. Available from: http://www.bbc.com/news/magazine-27189951.

7. Stall $\mathrm{R}$, Catania J. AIDS risk behaviors among late middle-aged and elderly Americans. The National AIDS Behavioral Surveys. Arch Intern Med 1994;154:57-63.

8. Goodroad BK. HIV and AIDS in people older than 50. A continuing concern. J Gerontol Nurs 2003;29:18-24.

9. Patel D, Gillespie B, Foxman B. Sexual behavior of older women: results of a random-digit-dialing survey of 2,000 women in the United States. Sex Transm Dis 2003;30:216-20.

10. Karlovsky M, Lebed B, Mydlo JH. Increasing incidence and importance of HIV/AIDS and gonorrhea among men aged $>/=$ 50 years in the US in the era of erectile dysfunction therapy. Scand J Urol Nephrol 2004;38:247-52.

11. Szirony TA. Infection with HIV in the elderly population. J Gerontol Nurs 1999;25:25-31.

12. Talashek ML, Tichy AM, Epping H. Sexually transmitted diseases in the elderly--issues and recommendations. J Gerontol Nurs 1990;16:33-40.

13. Whipple B, Scura KW. The overlooked epidemic: HIV in older adults. Am J Nurs 1996;96:22-8; quiz 29.

14. Allison-Ottey S, Weston C, Hennawi G, Nichols M, Eldred L, Ferguson RP. Sexual practices of older adults in a high HIV prevalence environment. Md Med J 1999;48:287-91.

15. Laumann EO, Glasser DB, Neves RC, Moreira ED Jr; GSSAB Investigators' Group. A population-based survey of sexual activity, sexual problems and associated help-seeking behavior patterns in mature adults in the United States of America. Int J Impot Res 2009;21:171-8.

16. Liu H, Lin X, Xu Y, Chen S, Shi J, Morisky D. Emerging HIV 


\section{ICUROLOGY}

epidemic among older adults in Nanning, China. AIDS Patient Care STDS 2012;26:565-7.

17. Centers for Disease Control and Prevention. Sexually trans-

\section{Sexual behavior and STD in elderly South Korean}

mitted disease surveillance 2017. Atlanta: U.S. Department of Health and Human Services; 2018. 
Supplementary material. Survey on sexual behavior and awareness on sexually transmitted disease

\section{A. Questions regarding sexual behavior}

1. How frequent did you have sexual intercourse during the last year?
1) 1-2 times per 1 month
2) 1-2 times per 3 months
3) 1-2 times per 6 months
4) 1-2 times per 1 year
5) None

2. What was the number of sexual partner during the last year?
1) 1
2) 2
3) More than 3
4) None

3. What was the type of sexual partner during the last year? Pick all.
1) Spouse
2) Couple
3) Prostitution
4) Etc.

4. Did you use condoms during sexual intercourse during the last year?
1) Almost always
2) More than half times
3) Less than half times
4) Never used

\section{For men only}

5. Do you think that you have decreased sexual function such as erectile dysfunction?

1) Severe

2) Moderate

3) Little

4) None

6. Do you use phosphodiesterase inhibitors (like Viagra) when you have sexual intercourse?

1) Yes

2) No

7. How much do you think phosphodiesterase inhibitors (like Viagra) contribute to your sexual life?
1) Very much
2) Moderate
3) Little
4) None 


\section{B. Questions regarding sexually transmitted diseases (STDs)}

8. Were you ever infected with sexually transmitted diseases?

1) Yes

2) No

If yes, when were you infected?

1) Over 10 years ago

2) Under 10 years ago

3) Not sure

9. What type of sexually transmitted diseases were you infected?

1) Urethritis

2) Gonorrhea

3) Syphilis

4) Herpes

5) Don’t know

10. What type of sexual partner were you infected from?

1) Spouse

2) Friend

3) Prostitute

4) Not sure

11. Where did you get treatment for sexually transmitted diseases?

1) Untreated

2) Hospital

3) Community health center

4) Etc.

\section{Questions regarding sexual health education}

12. Did you have any experience with sexual health education?

1) Yes

2) No

Are you willing to receive sexual health education for elderlies?

1) Yes

2) No

13. What type of institution do you prefer to receive sexual health education?

1) District office

2) Welfare center

3) Counseling center

4) Religious institution

5) Public health center

6) Professional organization

7) Etc. 
14. What type of personnel do you prefer to receive sexual health education?

1) Doctor/nurse

2) Counselor

3) Family

4) Friend

5) Etc. 
Supplementary Table 1. Frequency of sexual intercourse

\begin{tabular}{|c|c|c|c|c|c|c|c|c|c|c|}
\hline & \multicolumn{5}{|c|}{ Low-risk group $(n=204)$} & \multicolumn{5}{|c|}{ High-risk group $(n=133)$} \\
\hline & $\begin{array}{c}1-2 \text { times } \\
/ 1 \text { mo }\end{array}$ & $\begin{array}{c}1-2 \text { times } \\
/ 3 \text { mo }\end{array}$ & $\begin{array}{c}1-2 \text { times } \\
/ 6 \text { mo }\end{array}$ & $\begin{array}{c}1-2 \text { times } \\
/ 1 \mathrm{y}\end{array}$ & None & $\begin{array}{c}1-2 \text { times } \\
/ 1 \text { mo }\end{array}$ & $\begin{array}{c}\text { 1-2 times } \\
\text { / } 3 \mathrm{mo}\end{array}$ & $\begin{array}{c}1-2 \text { times } \\
/ 6 \text { mo }\end{array}$ & $\begin{array}{c}1-2 \text { times } \\
/ 1 \mathrm{y}\end{array}$ & None \\
\hline \multicolumn{11}{|l|}{ Age (y) } \\
\hline $60-64$ & $10(4.9)$ & $1(0.5)$ & $0(0.0)$ & $0(0.0)$ & $4(2.0)$ & $1(0.8)$ & $0(0.0)$ & $0(0.0)$ & $0(0.0)$ & $0(0.0)$ \\
\hline $65-70$ & $23(11.3)$ & $6(2.9)$ & $3(1.5)$ & $5(2.5)$ & $19(9.3)$ & $7(5.3)$ & $2(1.5)$ & $0(0.0)$ & $2(1.5)$ & $10(7.5)$ \\
\hline $71-80$ & $27(13.2)$ & $6(2.9)$ & $2(1.0)$ & $2(1.0)$ & $68(33.3)$ & $21(15.8)$ & $5(3.8)$ & $4(3.0)$ & $5(3.8)$ & $45(33.8)$ \\
\hline $81-90$ & $1(0.5)$ & $0(0.0)$ & $0(0.0)$ & $0(0.0)$ & $23(11.3)$ & $6(4.5)$ & $1(0.8)$ & $0(0.0)$ & $0(0.0)$ & $21(15.8)$ \\
\hline$\geq 91$ & $0(0.0)$ & $0(0.0)$ & $0(0.0)$ & $0(0.0)$ & $4(2.0)$ & $0(0.0)$ & $0(0.0)$ & $0(0.0)$ & $0(0.0)$ & $3(2.3)$ \\
\hline \multicolumn{11}{|l|}{ Sex } \\
\hline Male & $35(17.2)$ & $11(5.4)$ & $2(1.0)$ & $5(2.5)$ & $44(21.6)$ & $34(25.6)$ & $8(6.0)$ & $4(3.0)$ & $6(4.5)$ & $65(48.9)$ \\
\hline Female & $26(12.7)$ & $2(1.0)$ & $3(1.5)$ & $2(1.0)$ & $74(36.3)$ & $1(0.8)$ & $0(0.0)$ & $0(0.0)$ & $1(0.8)$ & $14(10.5)$ \\
\hline
\end{tabular}

Values are presented as number (\%). 
Supplementary Table 2. Number of sexual partners

\begin{tabular}{|c|c|c|c|c|c|c|c|c|}
\hline & \multicolumn{4}{|c|}{ Low-risk group $(n=204)$} & \multicolumn{4}{|c|}{ High-risk group ( $n=133$ ) } \\
\hline & 1 & 2 & Over 3 & None & 1 & 2 & Over 3 & None \\
\hline \multicolumn{9}{|l|}{ Age (y) } \\
\hline $60-64$ & $10(4.9)$ & $1(0.5)$ & $0(0.0)$ & $4(2.0)$ & $1(0.8)$ & $0(0.0)$ & $0(0.0)$ & $0(0.0)$ \\
\hline $65-70$ & $36(17.6)$ & $1(0.5)$ & $0(0.0)$ & $19(9.3)$ & $9(6.8)$ & $0(0.0)$ & $2(1.5)$ & $10(7.5)$ \\
\hline $71-80$ & $35(17.2)$ & $2(1.0)$ & $1(0.5)$ & $67(32.8)$ & $29(21.8)$ & $2(1.5)$ & $3(2.3)$ & $46(34.6)$ \\
\hline $81-90$ & $0(0.0)$ & $0(0.0)$ & $0(0.0)$ & $24(11.8)$ & $6(4.5)$ & $0(0.0)$ & $1(0.8)$ & $21(15.8)$ \\
\hline$\geq 91$ & $0(0.0)$ & $0(0.0)$ & $0(0.0)$ & $4(2.0)$ & $0(0.0)$ & $0(0.0)$ & $0(0.0)$ & $3(2.3)$ \\
\hline \multicolumn{9}{|l|}{ Sex } \\
\hline Male & $48(23.5)$ & $4(2.0)$ & $1(0.5)$ & $44(21.6)$ & $42(31.6)$ & $2(1.5)$ & $6(4.5)$ & 66 (49.6) \\
\hline Female & $33(16.2)$ & $0(0.0)$ & $0(0.0)$ & $70(34.3)$ & $2(1.5)$ & $0(0.0)$ & $0(0.0)$ & $14(10.5)$ \\
\hline
\end{tabular}

Values are presented as number (\%). 
Supplementary Table 3. Types of sexual partner

\begin{tabular}{|c|c|c|c|c|c|c|c|c|}
\hline & \multicolumn{4}{|c|}{ Low-risk group $(n=88)$} & \multicolumn{4}{|c|}{ High-risk group $(n=58)$} \\
\hline & Spouse & Couple & Prostitution & Etc. & Spouse & Couple & Prostitution & Etc. \\
\hline \multicolumn{9}{|l|}{ Age (y) } \\
\hline $60-64$ & $10(11.4)$ & $1(1.1)$ & $0(0.0)$ & $0(0.0)$ & $1(1.7)$ & $0(0.0)$ & $0(0.0)$ & $0(0.0)$ \\
\hline $65-70$ & $34(38.6)$ & $3(3.4)$ & $0(0.0)$ & $0(0.0)$ & $8(13.8)$ & $4(6.9)$ & $1(1.7)$ & $0(0.0)$ \\
\hline $71-80$ & $36(40.9)$ & $3(3.4)$ & $1(1.1)$ & $0(0.0)$ & $28(48.3)$ & $5(8.6)$ & $3(5.2)$ & $1(1.7)$ \\
\hline $81-90$ & $0(0.0)$ & $0(0.0)$ & $0(0.0)$ & $0(0.0)$ & $3(5.2)$ & $4(6.9)$ & $0(0.0)$ & $0(0.0)$ \\
\hline$\geq 91$ & $0(0.0)$ & $0(0.0)$ & $0(0.0)$ & $0(0.0)$ & $0(0.0)$ & $0(0.0)$ & $0(0.0)$ & $0(0.0)$ \\
\hline \multicolumn{9}{|l|}{ Sex } \\
\hline Male & $47(53.4)$ & $7(8.0)$ & $1(1.1)$ & $0(0.0)$ & $39(67.2)$ & $12(20.7)$ & $4(6.9)$ & $1(1.7)$ \\
\hline Female & $33(37.5)$ & $0(0.0)$ & $0(0.0)$ & $0(0.0)$ & $1(1.7)$ & $1(1.7)$ & $0(0.0)$ & $0(0.0)$ \\
\hline
\end{tabular}

Values are presented as number (\%). 
Supplementary Table 4. Condom use during sexual intercourse

\begin{tabular}{|c|c|c|c|c|c|c|c|c|}
\hline & \multicolumn{4}{|c|}{ Low-risk group $(n=85)$} & \multicolumn{4}{|c|}{ High-risk group $(n=54)$} \\
\hline & $\begin{array}{l}\text { Almost } \\
\text { always }\end{array}$ & $\begin{array}{l}\text { More than } \\
\text { half times }\end{array}$ & $\begin{array}{l}\text { Less than } \\
\text { half times }\end{array}$ & $\begin{array}{c}\text { Never } \\
\text { used }\end{array}$ & $\begin{array}{l}\text { Almost } \\
\text { always }\end{array}$ & $\begin{array}{l}\text { More than } \\
\text { half times }\end{array}$ & $\begin{array}{l}\text { Less than } \\
\text { half times }\end{array}$ & $\begin{array}{c}\text { Never } \\
\text { used }\end{array}$ \\
\hline \multicolumn{9}{|l|}{ Age (y) } \\
\hline $60-64$ & $0(0.0)$ & $0(0.0)$ & $2(2.4)$ & $10(11.8)$ & $0(0.0)$ & $0(0.0)$ & $0(0.0)$ & $1(1.9)$ \\
\hline $65-70$ & $0(0.0)$ & $0(0.0)$ & $0(0.0)$ & $35(41.2)$ & $1(1.9)$ & $0(0.0)$ & $1(1.9)$ & $9(16.7)$ \\
\hline $71-80$ & $1(1.2)$ & $0(0.0)$ & $0(0.0)$ & $33(38.8)$ & $2(3.7)$ & $0(0.0)$ & $1(1.9)$ & $32(59.3)$ \\
\hline $81-90$ & $0(0.0)$ & $0(0.0)$ & $0(0.0)$ & $1(1.2)$ & $2(3.7)$ & $0(0.0)$ & $0(0.0)$ & $5(9.3)$ \\
\hline$\geq 91$ & $0(0.0)$ & $0(0.0)$ & $0(0.0)$ & $0(0.0)$ & $0(0.0)$ & $0(0.0)$ & $0(0.0)$ & $0(0.0)$ \\
\hline \multicolumn{9}{|l|}{ Sex } \\
\hline Male & $1(1.2)$ & $0(0.0)$ & $1(1.2)$ & $50(58.8)$ & $5(9.3)$ & $0(0.0)$ & $2(3.7)$ & $45(83.3)$ \\
\hline Female & $0(0.0)$ & $0(0.0)$ & $0(0.0)$ & $29(34.1)$ & $0(0.0)$ & $0(0.0)$ & $0(0.0)$ & $2(3.7)$ \\
\hline
\end{tabular}

Values are presented as number (\%). 
Supplementary Table 5. Presence of erectile dysfunction

\begin{tabular}{|c|c|c|c|c|c|c|c|c|}
\hline & \multicolumn{4}{|c|}{ Low-risk group $(n=97)$} & \multicolumn{4}{|c|}{ High-risk group $(n=111)$} \\
\hline & Severe & Moderate & Little & None & Severe & Moderate & Little & None \\
\hline \multicolumn{9}{|l|}{ Age $(y)$} \\
\hline $60-64$ & $1(1.0)$ & $2(2.1)$ & $0(0.0)$ & $0(0.0)$ & $0(0.0)$ & $0(0.0)$ & $0(0.0)$ & $0(0.0)$ \\
\hline $65-70$ & 19 (19.6) & $18(18.6)$ & $4(4.1)$ & $2(2.1)$ & $4(3.6)$ & $5(4.5)$ & $7(6.3)$ & $0(0.0)$ \\
\hline $71-80$ & $4(4.1)$ & $22(22.7)$ & $10(10.3)$ & $4(4.1)$ & $31(27.9)$ & $25(22.5)$ & $11(9.9)$ & $1(0.9)$ \\
\hline $81-90$ & $5(5.2)$ & $2(2.1)$ & $1(1.0)$ & $1(1.0)$ & $15(13.5)$ & $3(2.7)$ & $3(2.7)$ & $1(0.9)$ \\
\hline$\geq 91$ & $1(1.0)$ & $1(1.0)$ & $0(0.0)$ & $0(0.0)$ & $3(2.7)$ & $0(0.0)$ & $0(0.0)$ & $0(0.0)$ \\
\hline \multicolumn{9}{|l|}{ Sex } \\
\hline Male & $30(30.9)$ & $45(46.4)$ & 15 (15.5) & $7(7.2)$ & $53(47.7)$ & $33(29.7)$ & $21(18.9)$ & $2(1.8)$ \\
\hline
\end{tabular}

Values are presented as number (\%). 
Supplementary Table 6. Use of phosphodiesterase-5 inhibitors

\begin{tabular}{|c|c|c|c|c|}
\hline & \multicolumn{2}{|c|}{ Low-risk group $(n=97)$} & \multicolumn{2}{|c|}{ High-risk group $(n=117)$} \\
\hline & Yes & No & Yes & No \\
\hline \multicolumn{5}{|l|}{ Age (y) } \\
\hline $60-64$ & $1(1.0)$ & $2(2.1)$ & $0(0.0)$ & $0(0.0)$ \\
\hline $65-70$ & $9(9.3)$ & $16(16.5)$ & $23(19.7)$ & $13(11.1)$ \\
\hline $71-80$ & $15(15.5)$ & $42(43.3)$ & $6(5.1)$ & $44(37.6)$ \\
\hline $81-90$ & $1(1.0)$ & $9(9.3)$ & $2(1.7)$ & $19(16.2)$ \\
\hline$\geq 91$ & $0(0.0)$ & $2(2.1)$ & $0(0.0)$ & $2(1.7)$ \\
\hline \multicolumn{5}{|l|}{ Sex } \\
\hline Male & $23(23.7)$ & $71(73.2)$ & $32(27.4)$ & $78(66.7)$ \\
\hline
\end{tabular}

Values are presented as number (\%). 
Supplementary Table 7. Contribution of phosphodiesterase-5 inhibitors to sexual life

\begin{tabular}{|c|c|c|c|c|c|c|c|c|}
\hline & \multicolumn{4}{|c|}{ Low-risk group $(n=97)$} & \multicolumn{4}{|c|}{ High-risk group $(n=117)$} \\
\hline & Very much & Moderate & Little & None & Very much & Moderate & Little & None \\
\hline \multicolumn{9}{|l|}{ Age (y) } \\
\hline $60-64$ & $1(1.0)$ & $0(0.0)$ & $2(2.1)$ & $0(0.0)$ & $0(0.0)$ & $0(0.0)$ & $0(0.0)$ & $0(0.0)$ \\
\hline $65-70$ & $3(3.1)$ & $8(8.2)$ & $9(9.3)$ & $4(4.1)$ & $1(0.9)$ & $6(5.1)$ & $4(3.4)$ & $0(0.0)$ \\
\hline $71-80$ & $6(6.2)$ & $11(11.3)$ & $24(24.7)$ & $13(13.4)$ & $3(2.6)$ & $19(16.2)$ & $17(14.5)$ & $2(1.7)$ \\
\hline $81-90$ & $0(0.0)$ & $1(1.0)$ & $2(2.1)$ & $5(5.2)$ & $0(0.0)$ & $5(4.3)$ & $3(2.6)$ & $1(0.9)$ \\
\hline$\geq 91$ & $0(0.0)$ & $0(0.0)$ & $1(1.0)$ & $1(1.0)$ & $0(0.0)$ & $1(0.9)$ & $1(0.9)$ & $0(0.0)$ \\
\hline \multicolumn{9}{|l|}{ Sex } \\
\hline Male & $10(10.3)$ & $20(20.6)$ & $38(39.2)$ & $23(23.7)$ & $4(3.4)$ & $31(26.5)$ & $25(21.4)$ & $3(2.6)$ \\
\hline
\end{tabular}

Values are presented as number (\%). 
Supplementary Table 8. History of infection with sexually transmitted disease and time of infection

\begin{tabular}{|c|c|c|c|c|c|c|c|c|}
\hline & \multicolumn{4}{|c|}{ Low-risk group ( $n=204)$} & \multicolumn{4}{|c|}{ High-risk group $(n=133)$} \\
\hline & \multirow{2}{*}{ Infected } & \multicolumn{3}{|c|}{ Time of infection } & \multirow{2}{*}{ Infected } & \multicolumn{3}{|c|}{ Time of infection } \\
\hline & & $>10 y$ & $\leq 10 y$ & Not sure & & $>10 y$ & $\leq 10 y$ & Not sure \\
\hline \multicolumn{9}{|l|}{ Age (y) } \\
\hline $60-64$ & $0(0.0)$ & $0(0.0)$ & $0(0.0)$ & $0(0.0)$ & $0(0.0)$ & $0(0.0)$ & $0(0.0)$ & $0(0.0)$ \\
\hline $65-70$ & $7(3.4)$ & $7(19.4)$ & $0(0.0)$ & $0(0.0)$ & $8(6.0)$ & $7(19.4)$ & $0(0.0)$ & $1(2.8)$ \\
\hline $71-80$ & $24(11.8)$ & $24(66.7)$ & $0(0.0)$ & $0(0.0)$ & $21(15.8)$ & $18(50.0)$ & $2(5.6)$ & $0(0.0)$ \\
\hline $81-90$ & $5(2.5)$ & $5(13.9)$ & $0(0.0)$ & $0(0.0)$ & $7(5.3)$ & $6(16.7)$ & $1(2.8)$ & $1(2.8)$ \\
\hline$\geq 91$ & $0(0.0)$ & $0(0.0)$ & $0(0.0)$ & $0(0.0)$ & $0(0.0)$ & $0(0.0)$ & $0(0.0)$ & $0(0.0)$ \\
\hline \multicolumn{9}{|l|}{ Sex } \\
\hline Male & $30(14.7)$ & $30(83.3)$ & $0(0.0)$ & $0(0.0)$ & $32(24.1)$ & $27(75.0)$ & $3(8.3)$ & $2(5.6)$ \\
\hline Female & $6(2.9)$ & $6(16.7)$ & $0(0.0)$ & $0(0.0)$ & $4(3.0)$ & $4(11.1)$ & $0(0.0)$ & $0(0.0)$ \\
\hline
\end{tabular}

Values are presented as number (\%). 
Supplementary Table 9. Type of sexually transmitted disease

\begin{tabular}{|c|c|c|c|c|c|c|c|c|}
\hline & \multicolumn{4}{|c|}{ Low-risk group $(n=36)$} & \multicolumn{4}{|c|}{ High-risk group $(n=36)$} \\
\hline & Urethritis & Gonorrhea & Syphilis & Herpes & Urethritis & Gonorrhea & Syphilis & Herpes \\
\hline \multicolumn{9}{|l|}{ Age (y) } \\
\hline $60-64$ & $0(0.0)$ & $0(0.0)$ & $0(0.0)$ & $0(0.0)$ & $0(0.0)$ & $0(0.0)$ & $0(0.0)$ & $0(0.0)$ \\
\hline $65-70$ & $1(2.8)$ & $5(13.9)$ & $0(0.0)$ & $1(2.8)$ & $1(2.8)$ & $5(13.9)$ & $0(0.0)$ & $1(2.8)$ \\
\hline $71-80$ & $1(2.8)$ & $16(44.4)$ & $2(5.6)$ & $1(2.8)$ & $3(8.3)$ & $16(44.4)$ & $0(0.0)$ & $0(0.0)$ \\
\hline $81-90$ & $0(0.0)$ & $3(8.3)$ & $0(0.0)$ & $0(0.0)$ & $2(5.6)$ & $4(11.1)$ & $0(0.0)$ & $0(0.0)$ \\
\hline$\geq 91$ & $0(0.0)$ & $0(0.0)$ & $0(0.0)$ & $0(0.0)$ & $0(0.0)$ & $0(0.0)$ & $0(0.0)$ & $0(0.0)$ \\
\hline \multicolumn{9}{|l|}{ Sex } \\
\hline Male & $2(5.6)$ & $21(58.3)$ & $2(5.6)$ & $2(5.6)$ & $5(13.9)$ & $26(72.2)$ & $0(0.0)$ & $0(0.0)$ \\
\hline Female & $0(0.0)$ & $3(8.3)$ & $0(0.0)$ & $0(0.0)$ & $1(2.8)$ & $1(2.8)$ & $0(0.0)$ & $1(2.8)$ \\
\hline
\end{tabular}

Values are presented as number (\%). 
Supplementary Table 10. Types of sexual partner that sexually transmitted disease was infected

\begin{tabular}{|c|c|c|c|c|c|c|c|c|}
\hline & \multicolumn{4}{|c|}{ Low-risk group $(n=36)$} & \multicolumn{4}{|c|}{ High-risk group $(n=36)$} \\
\hline & Spouse & Friend & Prostitution & Not sure & Spouse & Friend & Prostitution & Not sure \\
\hline \multicolumn{9}{|l|}{ Age (y) } \\
\hline $60-64$ & $0(0.0)$ & $0(0.0)$ & $0(0.0)$ & $0(0.0)$ & $0(0.0)$ & $0(0.0)$ & $0(0.0)$ & $0(0.0)$ \\
\hline $65-70$ & $1(2.8)$ & $1(2.8)$ & $3(8.3)$ & $2(5.6)$ & $2(5.6)$ & $2(5.6)$ & $4(11.1)$ & $0(0.0)$ \\
\hline $71-80$ & $3(8.3)$ & $5(13.9)$ & $14(38.9)$ & $1(2.8)$ & $0(0.0)$ & $4(11.1)$ & $13(36.1)$ & $4(11.1)$ \\
\hline $81-90$ & $2(5.6)$ & $0(0.0)$ & $2(5.6)$ & $0(0.0)$ & $0(0.0)$ & $2(5.6)$ & $3(8.3)$ & $1(2.8)$ \\
\hline$\geq 91$ & $0(0.0)$ & $0(0.0)$ & $0(0.0)$ & $0(0.0)$ & $0(0.0)$ & $0(0.0)$ & $0(0.0)$ & $0(0.0)$ \\
\hline \multicolumn{9}{|l|}{ Sex } \\
\hline Male & $2(5.6)$ & $6(16.7)$ & $19(52.8)$ & $3(8.3)$ & $0(0.0)$ & $6(16.7)$ & $20(55.6)$ & $5(13.9)$ \\
\hline Female & $4(11.1)$ & $0(0.0)$ & $0(0.0)$ & $1(2.8)$ & $2(5.6)$ & $2(5.6)$ & $0(0.0)$ & $0(0.0)$ \\
\hline
\end{tabular}

Values are presented as number (\%). 
Supplementary Table 11. Place where sexually transmitted disease was treated

\begin{tabular}{|c|c|c|c|c|c|c|c|c|}
\hline & \multicolumn{4}{|c|}{ Low-risk group $(n=36)$} & \multicolumn{4}{|c|}{ High-risk group $(n=36)$} \\
\hline & Untreated & Hospital & $\begin{array}{l}\text { Community } \\
\text { health center }\end{array}$ & Etc. & Untreated & Hospital & $\begin{array}{l}\text { Community } \\
\text { health center }\end{array}$ & Etc \\
\hline \multicolumn{9}{|l|}{ Age (y) } \\
\hline $60-64$ & $0(0.0)$ & $0(0.0)$ & $0(0.0)$ & $0(0.0)$ & $0(0.0)$ & $0(0.0)$ & $0(0.0)$ & $0(0.0)$ \\
\hline $65-70$ & $1(2.8)$ & $6(16.7)$ & $0(0.0)$ & $0(0.0)$ & $1(2.8)$ & $7(19.4)$ & $0(0.0)$ & $0(0.0)$ \\
\hline $71-80$ & $0(0.0)$ & $21(58.3)$ & $1(2.8)$ & $2(5.6)$ & $1(2.8)$ & $18(50.0)$ & $1(2.8)$ & $1(2.8)$ \\
\hline $81-90$ & $1(2.8)$ & $4(11.1)$ & $0(0.0)$ & $0(0.0)$ & $0(0.0)$ & $6(16.7)$ & $0(0.0)$ & $0(0.0)$ \\
\hline$\geq 91$ & $0(0.0)$ & $0(0.0)$ & $0(0.0)$ & $0(0.0)$ & $0(0.0)$ & $0(0.0)$ & $0(0.0)$ & $0(0.0)$ \\
\hline \multicolumn{9}{|l|}{ Sex } \\
\hline Male & $1(2.8)$ & $26(72.2)$ & $1(2.8)$ & $2(5.6)$ & $1(2.8)$ & $28(77.8)$ & $1(2.8)$ & $1(2.8)$ \\
\hline Female & $1(2.8)$ & $5(13.9)$ & $0(0.0)$ & $0(0.0)$ & $1(2.8)$ & $3(8.3)$ & $0(0.0)$ & $0(0.0)$ \\
\hline
\end{tabular}

Values are presented as number (\%). 
Supplementary Table 12. Experience with and intention to receive sexual health education

\begin{tabular}{|c|c|c|c|c|c|c|c|c|}
\hline & \multicolumn{4}{|c|}{ Low-risk group $(n=204)$} & \multicolumn{4}{|c|}{ High-risk group $(n=133)$} \\
\hline & \multicolumn{2}{|c|}{$\begin{array}{c}\text { Experience with } \\
\text { sexual health education }\end{array}$} & \multicolumn{2}{|c|}{$\begin{array}{l}\text { Intention to receive } \\
\text { sexual health education }\end{array}$} & \multicolumn{2}{|c|}{$\begin{array}{c}\text { Experience with } \\
\text { sexual health education }\end{array}$} & \multicolumn{2}{|c|}{$\begin{array}{l}\text { Intention to receive } \\
\text { sexual health education }\end{array}$} \\
\hline & Yes & No & Yes & No & Yes & No & Yes & no \\
\hline \multicolumn{9}{|l|}{ Age (y) } \\
\hline $60-64$ & $7(3.4)$ & $8(3.9)$ & $11(5.4)$ & $5(2.5)$ & $0(0.0)$ & $1(0.8)$ & $0(0.0)$ & $0(0.0)$ \\
\hline $65-70$ & $22(10.8)$ & $34(16.7)$ & $35(17.2)$ & $20(9.8)$ & $1(0.8)$ & $20(15.0)$ & $17(12.8)$ & $5(3.8)$ \\
\hline $71-80$ & $29(14.2)$ & $76(37.3)$ & $44(21.6)$ & $61(29.9)$ & $9(6.8)$ & $67(50.4)$ & $30(22.6)$ & $44(33.1)$ \\
\hline $81-90$ & $2(1.0)$ & $22(10.8)$ & $7(3.4)$ & $17(8.3)$ & $2(1.5)$ & $25(18.8)$ & $6(4.5)$ & $21(15.8)$ \\
\hline$\geq 91$ & $0(0.0)$ & $4(2.0)$ & $0(0.0)$ & $4(2.0)$ & $0(0.0)$ & $3(2.3)$ & $2(1.5)$ & $1(0.8)$ \\
\hline \multicolumn{9}{|l|}{ Sex } \\
\hline Male & $23(11.3)$ & $74(36.3)$ & $50(24.5)$ & $47(23.0)$ & $12(9.0)$ & $100(75.2)$ & $48(36.1)$ & $62(46.6)$ \\
\hline Female & $37(18.1)$ & $70(34.3)$ & $47(23.0)$ & $60(29.4)$ & $0(0.0)$ & $16(12.0)$ & $7(5.3)$ & $9(6.8)$ \\
\hline
\end{tabular}

Values are presented as number (\%). 


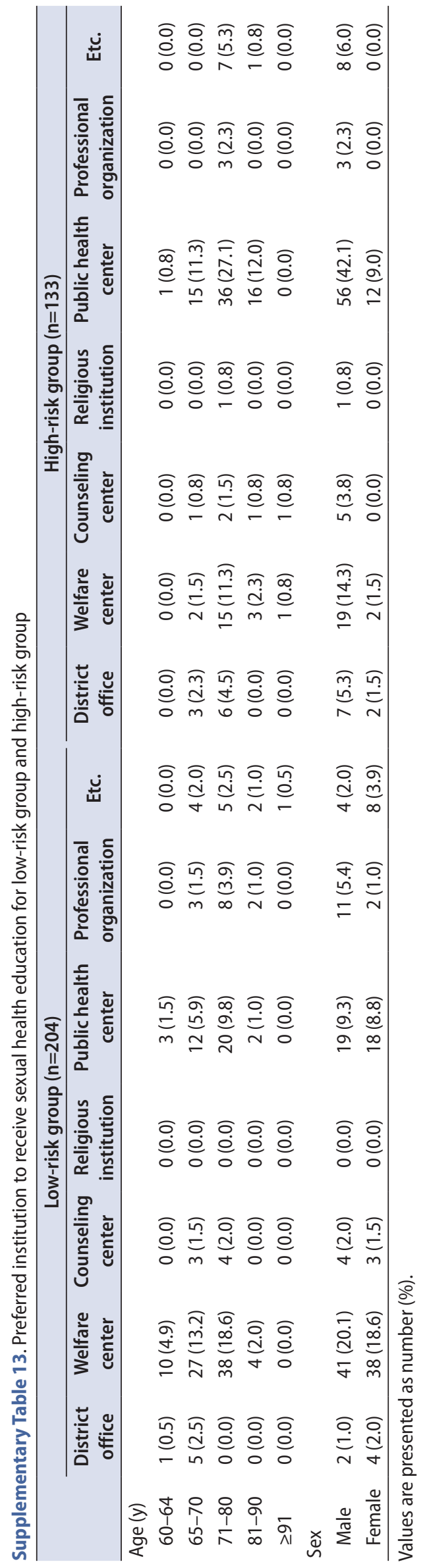


Supplementary Table 14. Preferred person to receive sexual health education for low-risk group and high-risk group

\begin{tabular}{|c|c|c|c|c|c|c|c|c|c|c|}
\hline & \multicolumn{5}{|c|}{ Low-risk group $(n=204)$} & \multicolumn{5}{|c|}{ High-risk group ( $n=133$ ) } \\
\hline & $\begin{array}{c}\text { Doctor/ } \\
\text { nurse }\end{array}$ & $\begin{array}{c}\text { Counseling } \\
\text { center }\end{array}$ & Family & Friend & Etc. & $\begin{array}{c}\text { Doctor/ } \\
\text { nurse }\end{array}$ & $\begin{array}{c}\text { Counseling } \\
\text { center }\end{array}$ & Family & Friend & Etc. \\
\hline \multicolumn{11}{|l|}{ Age $(y)$} \\
\hline $60-64$ & $7(3.4)$ & $7(3.4)$ & $0(0.0)$ & $1(0.5)$ & $0(0.0)$ & $1(0.8)$ & $0(0.0)$ & $0(0.0)$ & $0(0.0)$ & $0(0.0)$ \\
\hline $65-70$ & $21(10.3)$ & $24(11.8)$ & $0(0.0)$ & $1(0.5)$ & $1(0.5)$ & $14(10.5)$ & $7(5.3)$ & $0(0.0)$ & $0(0.0)$ & $0(0.0)$ \\
\hline $71-80$ & $39(19.1)$ & $32(15.7)$ & $1(0.5)$ & $1(0.5)$ & $4(2.0)$ & $40(30.1)$ & $22(16.5)$ & $0(0.0)$ & $2(1.5)$ & $6(4.5)$ \\
\hline $81-90$ & $5(2.5)$ & $6(2.9)$ & $0(0.0)$ & $0(0.0)$ & $2(1.0)$ & $17(12.8)$ & $5(3.8)$ & $0(0.0)$ & $2(1.5)$ & $1(0.8)$ \\
\hline$\geq 91$ & $0(0.0)$ & $0(0.0)$ & $0(0.0)$ & $0(0.0)$ & $1(0.5)$ & $1(0.8)$ & $1(0.8)$ & $0(0.0)$ & $0(0.0)$ & $0(0.0)$ \\
\hline \multicolumn{11}{|l|}{ Sex } \\
\hline Male & $38(18.6)$ & 35 (17.2) & $1(0.5)$ & $2(1.0)$ & $4(2.0)$ & $63(47.4)$ & $29(21.8)$ & $0(0.0)$ & $4(3.0)$ & $7(5.3)$ \\
\hline Female & $34(16.7)$ & $34(16.7)$ & $0(0)$ & $1(0.5)$ & $4(2.0)$ & $10(7.5)$ & $6(4.5)$ & $0(0.0)$ & $0(0.0)$ & $0(0.0)$ \\
\hline
\end{tabular}

Values are presented as number (\%). 